原著

\title{
脳温を指標とした重症くも膜下出血に対する 新しい脳保護療法の試み
}

\author{
神保洋之, 土肥 謙二, 望月由武人 \\ 小林信介，豊田泉，林宗貴 \\ 池田 幸想, 松本清
}

\section{A New Anti-inflammatory Neuroprotective Therapy for Severe Subarachnoid Hemorrhages Based on Brain Temperature}

Hiroyuki Jimbo, M.D., Kenji DohI, M.D., Yubuhito MochizukI, M.D., Nobusuke KobaYashi, M.D., Izumi Toyoda, M.D., Munetaka Hayashi, M.D., Yukio IkedA, M.D., and Kiyoshi Matsumoto, M.D.

Department of Neurosurgery, Shiwa University School of Medicine, Tokyo, Japan

Summary: A new therapeutic modality should be considered to improve overall results of severe subarachnoid hemorrhage ( $\mathrm{SAH}$ ). Hypothermia has been assumed to be one promissing therapeutic option for severe SAH patients. However, it has not produced acceptable results. We recently developed a new anti-inflammatory neuroprotective therapy with the use of indomethacin (IND) and etodolac (ETD) as a cyclooxygenase (COX) inhibitor.

Between July 1998 and June 1999, 23 severe aneurysmal SAH patients (4 WFNS Grade 4 and 19 Grade 5) were enrolled. IND (6 mg/kg/day) or ETD (16 mg/ $\mathrm{kg} /$ day) were employed for all patients. Brain temperatures were measured with a ventricle intracranial pressure (ICP) monitor catheter and controlled between $34.5^{\circ} \mathrm{C}$ and $36.5^{\circ} \mathrm{C}$. The CSF samples were obtained from catheter, and inflammatory cytokine (IL1- $\beta$ ) was measured. The patients with uncontrollable ICP or/and brain temperature over $37.5^{\circ} \mathrm{C}$ were treated by pharmacological brain hypothermia.

The CSF levels of IL- $1 \beta$ were reduced sequentially compared with severe SAH patients who underwent conventional therapy $(n=18)$. The outomes were as follows: good recovery, 3 ; moderate disability, 2; and severe disability, 3 patients in the Glasgow Outome Scale.

It is concluded that pharmacological brain cooling may impove the outcomes of serious patients by reducing the inflammatory response of the brain after SAH.

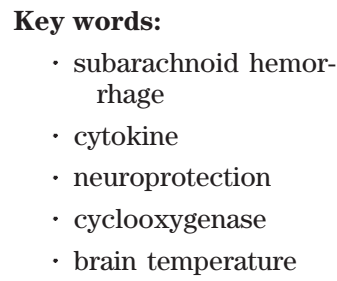

Surg Cereb Stroke (Jpn) 29: 335-338, 2001

\section{はじめに}

重症くも膜下出血に扔いては，、次性㧍よび二次性の脳
損傷を視野に人れた脳保護療法が必須であり，低体温療法 がその治療法として期待されてきた。しかしながら，厚生 省班会議の成果に㧍いてみられるように，従来の泠却マッ 昭和大学医学部 脳神経外科(受稿日 2000.8.3)〔連絡先： $7142-8555$ 東京都品川区旗の台 $1^{-}-5-8$ 昭和大学医学部 脳神経外科 神保 洋之] [Mailing address: Hiroyuki Jimbo, M.D., Department of Neurosurgery, Showa University School of Medicine, 1-5-8 Hatanodai, Shinagawa-ku, Tokyo $142-8555$, Japan] 


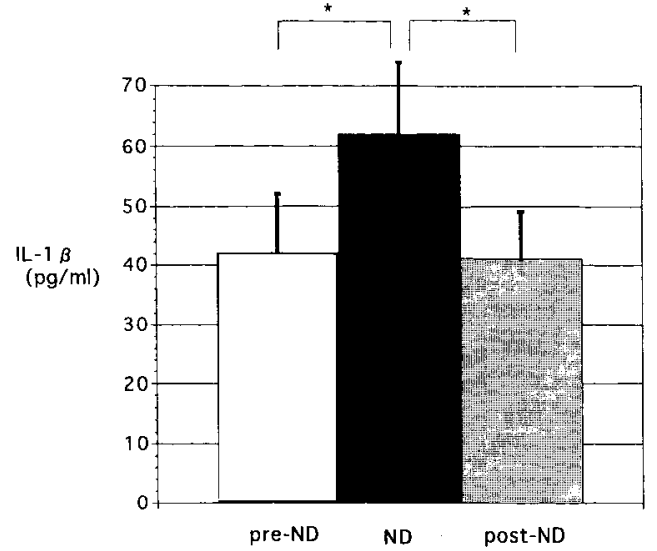

Fig. 1 The CSF levels of IL-1 $\beta$ increased significantly in the day of neurological deterioration (chi-square test). ND: neurological deterioration

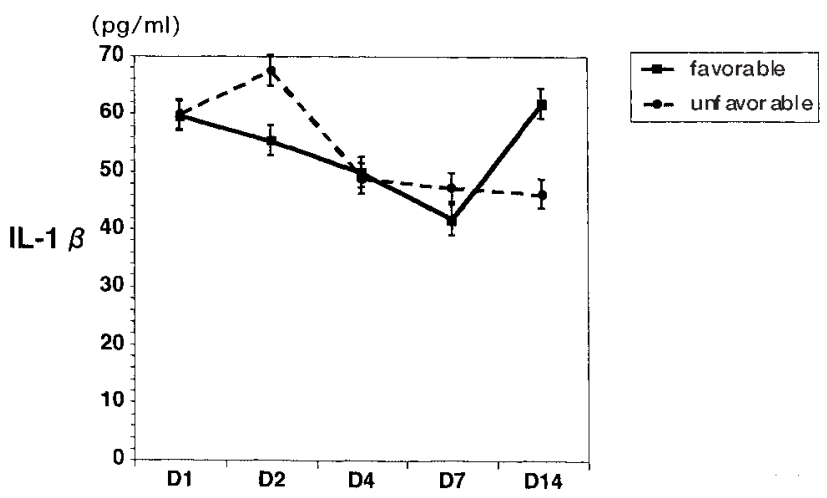

Fig. 2 The CSF levels of IL-1 $\beta$ elevated significantly in day 2 (chi-square test). favorable: favorable outcome in Glasgow outcome scale (GR, MD), unfavorable: unfavorable outcome in Glasgow outcome scale (SD, VS and dead)

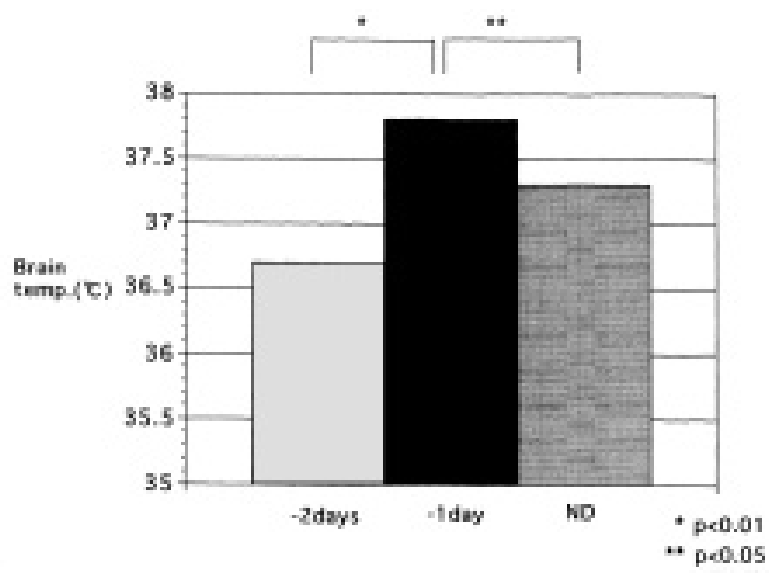

Fig. 3 Brain temperature elevated significantly in a day before neurological deterioration (chi-square test).

ND: neurological deterioration
卜を用いた低体温療法では，必ずしも满足する効果が得ら

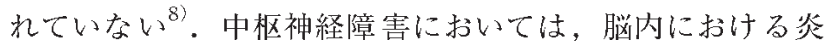
症性サイトカインが上昇すること，プロスタグランジンの 合成に必要な, シクロオキシゲナーゼ (COX) - 2 の発現が 報告されている ${ }^{13)}$.また，発熱の機序としては，内因性 発熱物質である, インターロイキン $1 \beta$ (IL-1 $\beta$ ), 腫瘍壞 死因个(TNF- $\alpha$ )などのサイトカインが免疫系の紐胞で産 生されそれが脳に作用してプロスタダランジン E2 (PGE2) の放出を促し，このPGE2が神経に作用して発熱を引き起 こすとされる ${ }^{11)}$. 脳内の炎症性サイトカインや, フリー ラジカルは，低温によって発現が抑制される1)9715)。しか し，われわれは，炎症性サイトカインの発現とそれに伴う プロスタダランジンの発現を薬理学的に直接抑制し，加え て脳内熱蛙留を防止する新しいシステムを開発すれば，低 体温だけに依存することなく脳における炎症作用, 二次的 脳損傷を抑制でき，また脳温管理も行えるとの作業仮説を たてた。そこで，くも膜下出血患者に扔いて，炎症性开イ トカインの動態と脳温の変化との関連性を検討し, 炎症性 サイトカインとプロスタグランジンの産生を抑制できる COX 阻害剂の臨床応用を試夕た。

\section{対象と方法}

前期；1997年4月より1998年 3 月に扔いて，直達手術 を施行し，通常の管理を行ったくも膜下出血患者 35例 (そのうち重症例は, WFNS grade IV 7 例, grade V 11 例，平均年齢 66.3 歳)に脳室に留置した脳温脳圧測定カテ 一テル (Camino-4HMT) より, 発症後 Day $0,1 ， 2 ， 4,14$ П 目に罷液を採双し，IL-1 $\beta$ をELISA 法によって測定した。 神経学的所見を連 П記録し, 脳温とIL-1 $\beta$ 押よび神経学的 患化の関倸を比較した。後期；1998年 7 月より 1999 年 6 月までに昭和大学医学部偷理委員会の承認のもと, 十分な インフォームドコンセントを行い, 直達手術を施行した重 症くも膜下出血患者 23 例 (WFNS grade IV 4 例, grade V 19 例, 平均年齢68. 歳)に脳温脳圧測定カテーテル留置後, 以下の方法によるCOX 阻害率を用いた pharmacological brain cooling (PBC) を実施した。(1) 脳温が $37.5{ }^{\circ} \mathrm{C}$ 以上で 脳圧が $20 \mathrm{mmHg}$ 以下の患者 (pharmacologic al normothermia) 16例；COX阻害㓲である indomethacin $6 \mathrm{mg} / \mathrm{kg}$ dayあるいは選択的 COX-2 阻害骺である etodolac 16 $\mathrm{mg} / \mathrm{kg} / \mathrm{day}$ 使用し, 脳温を $37.5{ }^{\circ} \mathrm{C}$ 以下に保った。(2) (1)の方法では，脳温あるいは脳圧がコントロールできな い患者 (pharmacological hypothermia) 7 例; 熱放散冷却 法として，片側鼻腔よりカテーテルを挿人し，両鼻腔を air leakageのないように閉塞し, 冷気を送気して, 口腔 バイトブロックより排気する人工的上気道換気を作り，脳 内蓄熱を防止した。冷却マットを用いずに室温を冷しさら 
にCOX 阻害剂を用いて脳温を $33.5{ }^{\circ} \mathrm{Cから} 34.5{ }^{\circ} \mathrm{C}$ の間に保 った 。この間消化管潰瘍の予防として粘膜保護剂とプロ トンポンプインヒビターを併用した。前期と同様に脳室力 テーテルから賄液を採取し IL-1 $\beta$ を経時的に測定した。

\section{結 果}

\section{1. 通常管理群における髄液中のIL-1 $\beta$, 脳温の变化}

神経学的所見の患化は, 35 例中 11 例であった。年の内 訳は, Grade II 4例, Grade III 3例, Grade IV 2例, Grade V 2 例で, 髄液中のIL- $1 \beta$ は, 神経学的患化が認め られた時期の前後がそれぞぞれ $41.1 \pm 9.3 \mathrm{pg} / \mathrm{ml}$ と $40.2 \pm$ $8.2 \mathrm{pg} / \mathrm{ml}$ に対して患化の認められた時期には $61.9 \pm 10.2$ $\mathrm{pg} / \mathrm{ml}$ と有意に上昇した (Fig. 1). 予後良好例 (Glasgow outcome scale; GR 拉よび MD, n=21) と予後不良例 ( $\mathrm{SD}$, VS扔よび dead， n=14）を比較すると, 発症初期には予後 不良例は，良好例に比較して高い傾向(Day 2 では，良好 例 $56.4 \pm 16.2 \mathrm{pg} / \mathrm{ml}$ ，不良例 $68.2 \pm 17.4 \mathrm{pg} / \mathrm{ml}$ ) が認められ たのちに徐々に減少し, Day 14 に扔いては良好例のほう が高く, 良好例 $61.8 \pm 44.7 \mathrm{pg} / \mathrm{ml}$, 不良例 $46.2 \pm 36.3 \mathrm{pg} /$ $\mathrm{ml}$ であった(Fig. 2).また, 脳温は, 神経学的所見の患化 が認められる 1 П前に $36.7^{\circ} \mathrm{C}$ から約 1 度上昇し $37.8^{\circ} \mathrm{Cにな}$ り, 神経学的所見が生じたПには低下したもののまだ $37.3^{\circ} \mathrm{C}$ と高い傾向があった(Fig. 3).

\section{PBC による脳温の抑制効果}

通常の管理を行った重傷症例群 (18例)に比べ, PBCを 施行した群 (23例) では, 初期の 1 迭間の間は $37^{\circ} \mathrm{C}$ 以下と 脳温上昇が抑制され, 復温期以降に脳温が逆転する傾向が 認められた (Fig. 4).

\section{PBC による喵液中IL- $1 \beta$ 濃度の抑制効果}

重症例に扮ける賄液中のIL-1 $\beta$ は, PBC 施行群に㧈い て経時的に $50 \mathrm{pg} / \mathrm{ml}$ 以下で, 通常管理群に比べて抑制さ れている傾向が認められた（Fig. 5)。

\section{4. $\mathrm{PBC}$ 群の予後}

来院時 Grade IV 4 例, Grade V 19 例の 3 力月後の扔け る予後は, good recovery: 3 例 (Grade IV 1 例, Grade V 2例), moderate disability; 2 例 (Grade V 2 例), severe disability; 3 例 (Grade IV 2 例, Grade V 1例), vegetative state; 1 例 (全例 Grade V), dead; 14 例 (全例 Grade V) であった。

\section{考察}

重症くも膜下出血患者の管理においては, 脳内の変化を 神経学的所見の㤟化や脳腫脹による頭蓋内圧上昇の生じる

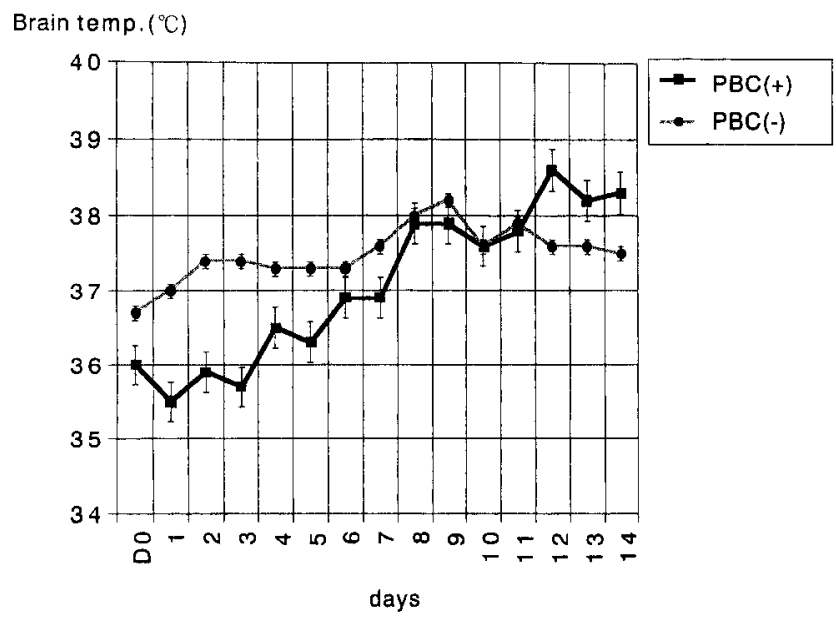

Fig. 4 The sequential change of brain temperature of PBC $(+)$ group were controlled in the early phase after onset of subarachnoid hemorrhage. PBC: pharmacological brain cooling

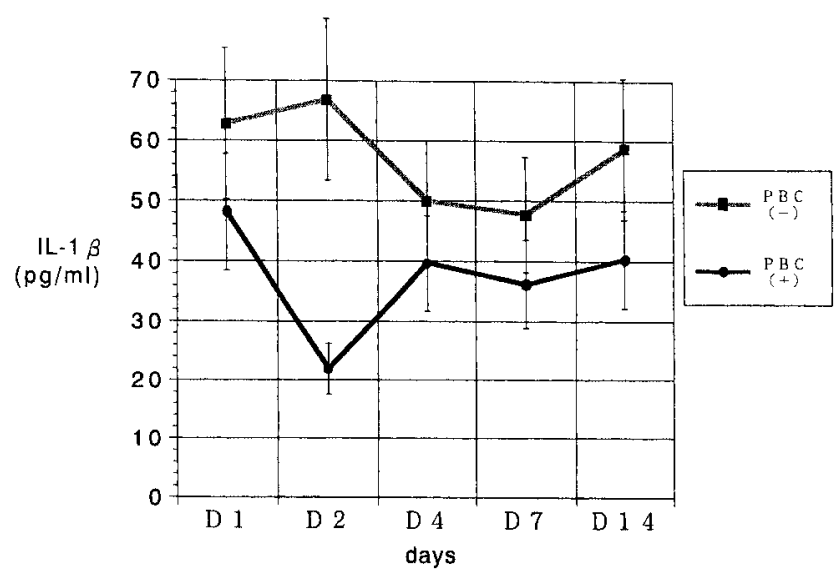

Fig. 5 The CSF levels of IL-1 $\beta$ decreased sequentially in the PBC $(+)$ group compared with PBC ( -) group. PBC: pharmacological brain cooling

前に早期にとらえることは難しい。われわれは, 重症くも 膜下出血後の二次的脳損傷として脳に㧍ける炎症反応子な わち炎症性サイトカインやフリーラジカルの発現による脳 損傷の拡大を，くい止めることを目標とした。年のために は, 脳に扔ける炎症反応の進行を早期に把握する指標が必 岁であり, 䯇液中のサイトカイン濃度を real timeに测定 できない現状に扔いて，発熱の機序に着目した。現在，発 熱の機序としては, 免疫系練胞で産生されたサイトカイン (IL-1 や TNF- $a$ ) が, 脳に作用して PGE2 の放出を促し, PGE2 は温度感受性ニューロンに作用して発熱を引き起こ すとされる11)。サイトカイン情報を神経系情報へ变換す る部位としては, 脳内に㧈いては脳室周囲器官(第:脳室 前壁部から腹側視交叉に至る領域), 血管内皮紐胞などが 
あげられ、これらの部位に扮ける PGE2やCOX-2の発現 が確認されている7 ${ }^{72)}$. くも膜下出血に扔いては, 髄液中 のサイトカインの上昇が報告され市，わ机われも血清中 に比べて能迹中の方がはるかに高いことを確認している。 すなわち, 脳損傷による脳内の炎症性サイトカインの産生 は発熱を引き起こし，これは脳温に反映されるものと考え られる。われわれの結果も, 神経学的㤟化の生じた時期に 髄液中 IL-1 $\beta$ と脳温の上昇が- - 致しており, 脳温の変化は, 脳内の炎症性反応の指䌘となりうるものと考元られた。

COX 阻害剂である ind ometacin 户 e todolac などの非久 テロイド性抗炎症薬 (NSAIDs) は, 一般治療に用いられて いるが, COX 活性が関与する多くの中枢神経系疾患への 応用が期待されている ${ }^{10)}$. その効果としては，1）脳圧降 下作用 ${ }^{4}$ ，2）炎症性サイトカインやNOSなどの neurotoxic factorの産生抑制, 3) 脳温上昇の予防（PGE2や炎 症性サイトカインの抑制），4）脳浮腫の抑制，5）脳血液 関門の維持, 透過性立進の抑制，6）フリーラジカルの抑 制効果などがある275). pharmacological normothermia 群 では、これらの直接的薬理作用により，平温に打ける管理 で二次的脳損傷の搪大を予防できる可能性が示唆された が，穴れでは脳損傷の拡大を抑えきれない症例が存在する のも事実であり，これらに関しては pharmacological hypothermia を施行した。低体温下でのくも膜下出血患者 の管理に扔いて hypovolemiaの原因として問題となる, 末梢血管抵抗の增大, 多尿や低ナトリウム血症は, COX 阻害剂の併用により抑制できる可能性がある ${ }^{6}$.

COX 阻害剂を用いた pharmacological brain coolingは, その直接的薬理作用により,できるだけ低温に依存せずに， 脳に扮ける炎症反応を抑制し，二次的脳損傷の拡大を予防 しょうとする新しい脳保護療法である。今回, 最重症のく も荫下出血症例に対しての試みに执いて，关の転㷌を考虑 すると primary brain damage(不可逆的脳損傷)の强い症 例に扔いては，十分な效果は認められなかった。現時点に おいてはいまだに不可逆的障害なのか可逆的なのかを早期 に判定する方法はないのが現状であり，その判定のために 待機する時間を費やすことは，その間にcytokine surge が生じ, 二次的脳損傷の搪大が進行してしまう可能性があ
る. 最重症の症例であっても, 来院早期からの脳保護療法 を積極的に施行することによって，救命のみならず機能的 予後の改善をも期待しうるものと考えられる。

\section{文献}

1) Dekosky ST, Miller PD, Sty ren S, et al: Interleukin-1 $\beta$ elevation in CSF following head injury in humans is attenuated by hypothermia. J Neurotrauma 11: 106, 1994

2）土肥謙二, 神保洋之, 池田幸稔：サイタロオキシダナーゼ (COX) 阻害剂を用いた脳温管理法。治療 $82(2)$ ：154-156, 2000

3) Gaetani P, Tartara F, Pignatti P: Cisternal CSF levels of cytokines after subarachnoid hemorrhage. Neurol Res 20 (4): 337-342, 1998

4) Harigan MR, Tuteja S, Neudeck BR: Indomethacin in management of elevated intracranial pressure; a review. J Neurotrauma 14: 637-650, 1997

5）池田幸稔, 佐藤和恵, 土肥謙二, ほか：Cyclooxygenase (COX) - 2 選択的阻害楽 etodolac $の$ superoxide radical 消去 能。医学のあゆみ $192(11): 1139-1140,2000$

6）神保洋之, 土肥謙二, 今泉陽一, ほか：重症くも膜下出血 に対する pharmacological brain hy pothermiaの試み. The Mt Fuji Workshop on CVD 18: 177-183, 2000

7) 片㴊俊彦：発熱とサイトカイン. Clin Neurosci 16 (4) : 425427, 1998

8）片岡喜由：軽微低体温療法による脳卒中治療の基礎的検討 と臨床手技の確立に関方石研究. 1997, pp 163-173

9) Kataoka K, Yanase H: Mild hy pothermia- a revealed countermeasure against ischemic neuronal damage. Neurosci Res 32: 103-117, 1998

10) Kaufman WE: Cyclooxygenase and central nervous system. Prostaglandins 54: 601-624, 1997

11）松村 絜, 小林茂夫：発熟一脳内プロスタグランデイン䒺 の局在.医学の市ゆみ $193(4): 235-239,2000$

12) Matumura $\mathrm{K}$ : Brain endothelial cells express cyclooxygenase-2 during lipopolysaccaride-induced fever: light and electron microscopic immunocytochemical studies. J Neurosci 18: 6279-6289, 1998

13) Nogawa S: Cyclooxygenase-2 gene expression in neurons contributes to ischemic brain damage. J Neurosci 17: $2766^{-2755,} 1998$

14) Osuka K, Suzuki Y, Tanazawa T: Interleukin-6 and development of vasospasm after subarachnoid hemorrhage. Acta Neurochir (Wien) $140(\mathbf{9})$ : 943-951, 1998

15) Si QS, Nakamura Y, Kataoka K: Hypothermic suppression of microgial activation in culture: inhibition of cell proliferation and production of nitric oxide and super oxide. Neuroscience 81: 223-229, 1997 